Riwayat Artikel: Diterima 21 Mei 2017; Direvisi 17 Juli 2017; Disetujui 18 Juli 2017; dan Dipublikasikan 26 Juli 2017

\title{
PERANCANGAN PESAN KOMUNIKASI KOMUNITAS HONG DALAM SOSIALISASI MAINAN DAN PERMAINAN TRADISIONAL SUNDA
}

\section{DESIGN OF COMMUNICATION MESSAGES HONG COMMUNITY IN SOCIALIZATION OF SUNDANESE TRADITIONAL TOYS AND GAMES}

\author{
Santi Susanti, Yuni Nurtania \\ (santisusanti2202@gmail.com; yuninurtania82@gmail.com) \\ (Program Studi Televisi dan Film, FIKOM, UNPAD; Magister Ilmu Komunikasi, \\ FIKOM, UNPAD)
}

\begin{abstract}
Abstrak
Komunitas Hong sebagai Pusat Kajian Mainan Rakyat Jawa Barat, memiliki tujuan melestarikan mainan dan permainan rakyat Jawa Barat serta merekonstruksi mainan rakyat yang bersumber dari tradisi lisan maupun tulisan dari naskah-naskah kuno. Dalam upaya pelestarian tersebut, Komunitas Hong pun mengenalkan mainan rakyat kepada masyarakat, terutama anak-anak, dengan tujuan menanamkan nilai-nilai pendidikan masyarakat kepada seorang anak agar ia mengenal diri, lingkungan dan Tuhannya. Penelitian ini bertujuan mengidentifikasi dan menganalisis proses perancangan pesan komunikasi Komunitas Hong dalam mensosialisasikan permainan dan mainan rakyat Jawa Barat. Hasil penelitian memunculkan lima kelompok yang menjadi sasaran komunikasi komunitas Hong, yakni publik, pemerintah, sesama anggota, mitra kerja dan sponsor. Adapun proses perancangan komunikasi Komunitas Hong yang ditujukan kepada khalayak sasarannya, dibagi ke dalam lima tahap sebagai berikut :(1) menentukan sasaran komunikasi, (2) identifikasi khalayak sasaran, (3) mendefinisikan sistem pengelolaan kegiatan komunikasi, (4) penyiapan sarana dan prasarana, dan (5) pengiriman pesan.
\end{abstract}

Kata Kunci: Pelestarian Budaya, Mainan Rakyat, Permainan Rakyat

\begin{abstract}
Hong Community as study center of traditional toys in West Java was formed with the intention of preserving traditional toys and folk games in West Java. As part of the effort to introduce traditional toys, especially to children. This study aims to identify and analyze the process of designing communication messages in the community of Hong in connection to the effort of socializing folk games and traditional toys in West Java. This study evolved five groups of communication target of Hong Community: the public, the government, fellow community members, working partner, the sponsors. The designing process of community communication that Hong Community uses to address its target audience, can be divided into 5 (five) stages as follows: (1) to define communication goals, (2) to identify the target audience, (3) to define the management system of communication event, (4) preparation of facility and infrastructure, and (5) message delivery.
\end{abstract}

Keywords: Cultural Preservation, Traditional Toys, Folk Games

\section{Pendahuluan}

Ada satu komunitas di Bandung yang didirikan untuk melestarikan mainan dan permainan tradisional rakyat, terutama dari Jawa Barat, yaitu Komunitas Hong. Komunitas ini didirikan pada tahun 2003 oleh M. Zaini Alif, yang sejak 1996 secara aktif meneliti mengenai mainan dan permainan rakyat. Komunitas Hong pun berkembang menjadi Pusat Kajian Mainan Rakyat yang bertekad melestarikan mainan dan permainan rakyat sebagai salah satu identitas bangsa. Tak hanya menjadi tempat berkumpul, komunitas ini juga menjadi wadah pencinta, peneliti dan produsen mainan anak. Komunitas Hong terus menggali dan merekonstruksi mainan rakyat, baik dari tradisi lisan maupun naskah-naskah kuno. Komunitas Hong berusaha mengenalkan mainan rakyat dengan tujuan menanamkan pola 
pendidikan masyarakat buhun, masyarakat yang memegang adat istiadat Parahyangan (Sunda) agar seorang anak mengenal diri, lingkungan dan Tuhannya.

Komunitas Hong menggali potensi dan nilai-nilai dari permainan tradisional untuk dikenalkan kepada anak-anak sekarang yang lebih mengenal permainan modern melalui gadget yang dimilikinya. Komunitas mainan rakyat ini berusaha memperkenalkan mainan rakyat juga melakukan binaan budaya bermain anak melalui beberapa promosi dan terus melakukan sosialisasi dengan aktif mengadakan pelatihan (workshop), kerja sama dengan beberapa mitra seperti lembaga pendidikan dan instansi serupa turut serta dalam berbagai event. Selain itu, Komunitas Hong juga mengembangkan produk mainan rakyat sebagai hasil pengembangan mainan anak yang ada untuk kebutuhan dalam dunia pendidikan.

Pelestarian permainan tradisional ini terus dikembangkan untuk melanggengkan dan menambah pengetahuan permainan tradisional. Untuk mewujudkan hal tersebut, Komunitas Hong telah menerapkan berbagai kegiatan antara lain pembuatan Kampung Kolecer, tempat melatih mainan dan permainan rakyat yang ada di Kampung Bolang, Desa Cibuluh, Kecamatan Tanjungsiang, Kabupaten Subang. Juga mendirikan Museum Mainan Rakyat di Bandung yang menyimpan serta memamerkan koleksi beberapa perangkat mainan untuk mengangkat dan memperkenalkan mainan rakyat dan menyelenggarakan Festival Kolecer, yaitu festival mainan rakyat dengan berbagai upacara adat.

Komunitas Hong memiliki banyak rencana untuk terus melestarikan permainan tradisional. Selain untuk melakukan workshop ke beberapa daerah, juga mendirikan arena permainan bernama Pakarangan Ulin di Dago Pakar, Bandung. Upaya promosi dan sosialisasi yang dilakukan oleh Komunitas Hong selain mampu untuk mengenalkan keberadaan komunitas ini kepada masyarakat dan instansi pemerintah maupun pihak swasta, saat ini dapat memberikan suatu peluang usaha kepada anggota Komunitas Hong agar dapat memperoleh penghasilan sendiri. Di antaranya melalui pesanan membuat mainan dan beberapa atribut kesundaan seperti pakaian dan ikat kepala, juga memenuhi undangan mengisi berbagai acara.

Untuk menjaga eksistensinya dalam melestarikan dan mengembangkan mainan serta permainan rakyat Jawa Barat, Komunitas Hong terus melalukan upaya sosialisasi dan kerja sama dengan berbagai pihak yang mendukung keberlangsungan komnitasnya, baik dari kalangan internal maupun eksternal. Jalinan komunikasi tersebut penting artinya bagi keberlangsungan kegiatan komunitas dalam mempertahankan kelestarian budaya maupun memberikan pendidikan kepada anak-anak mengenai nilai-nilai positif dalam mainan dan permainan rakyat yang berlandaskan kearifan lokal masyarakat setempat. Untuk itu, penelitian ini difokuskan pada perancangan pesan yang dilakukan oleh Komunitas Hong dalam rangka sosialisasi mainan dan permainan tradisional rakyat Jawa Barat.

Subjek ini menarik untuk diteliti dengan alasan hasil penelitian ini dapat dijadikan sebagai bahan kajian bagi komunitas Hong dalam menentukan strategi komunikasi yang lebih efektif . Penelitian ini juga memiliki arti strategis bagi pelestarian nilai-nilai budaya Sunda buhun yang dapat diwariskan secara turun temurun.

Penelitian sejenis yang pernah ada antara lain yang dilakukan oleh M. Zaini Alif, mengenai Perubahan dan Pengembangan Bentuk, Fungsi dan Material Mainan dalam Permainan Anak di Masyarakat Sunda. Penelitian Tesis di tahun 2006 pada Program Pascasarjana Institut Teknologi Bandung ini, membahas tentang mainan dan permainan masyarakat 
Sunda, yang dilatarbelakangi oleh adanya keprihatinan peneliti akan kelestarian jenis mainan dan permainan tradisional yang ada. Permainan tradisional sudah berubah dan tergeser oleh mainan-mainan yang memakai material buatan. Hal ini sejalan dengan kemajuan dan perubahan pola asuh anak. Penelitian ini menghasilkan 'deskripsi dan dokumentasi mengenai bentuk, fungsi dan material dari berbagai jenis mainan yang ada di masyarakat Sunda serta perubahan bentuk, material yang digunakan, cara bermain dan perkembangannya di masa kini.'

Kemudian penelitian Arman Yonathan, yang berjudul 'Perancangan Buku 'Ulin, Yu!!' sebagai upaya pelestarian Permainan Rakyat Jawa Barat', yang dihasilkan dalam bentuk skripsi pada Program Sarjana Desain Komunikasi Visual Universitas Maranatha, Bandung pada tahun 2009. Penelitian ini membahas tentang pelestarian permainan rakyat daerah Jawa Barat melalui penggunaan media fotografi sebagai media dokumentasi untuk menciptakan visual dari permainan tradisonal tersebut. Selanjutnya visualvisual yang berasal dari fotografi tersebut akan dilengkapi dengan desain grafis untuk lebih menguatkan pesannya. Fotografi dan desain grafis yang sudah ada akan diaplikasikan ke dalam bentuk sebuah buku sehingga memiliki alur cerita yang bersifat naratif sehingga tercipta komunikasi yang menarik.

Penelitian ini menghasilkan perancangan buku 'Ulin Yu!!' yang memperkenalkan permainan rakyat yang menggunakan alat dan permainan rakyat yang dimainkan secara massal, yang berisikan visual-visual yang berasal dari fotografi dan desain grafis dan memuat ketentuan-ketentuan permainan serta nilai filosofis yang terkandung di dalam permainan tersebut. Perancangan buku dilakukan untuk menginformasikan tentang nilai-nilai dan manfaat-manfaat yang dimiliki oleh permainan rakyat, supaya dapat meningkatkan kesadaran masyarakat akan pentingnya melestarikan kebudayaan asal, supaya permainan rakyat daerah Jawa Barat tidak hilang begitu saja.

\section{Metodologi}

Pendekatan yang digunakan dalam penelitian ini adalah pendekatan kualitatif. Pendekatan ini dipakai karena peneliti bermaksud memperoleh gambaran yang mendalam mengenai perancangan pesan komunikasi Komunitas Hong dalam melestarikan permainan dan mainan rakyat Jawa Barat.

Adapun metode yang digunakan adalah studi kasus. Menurut Mulyana (2006: 201), studi kasus adalah uraian dan penjelasan komprehensif mengenai berbagai aspek seorang indiidu, suatu kelompok, suatu organisasi (komunitas), suatu program atau suatu situasi sosial.

Studi kasus memiliki tujuan ganda. Di satu pihak, studi kasus berusaha memahami kelompok ang ditelaah, baik anggota dari kelompok tersebut, bentuk kegiatan, interaksi dan cara kelompok itu berhubungan dengan dunia di luar mereka. Di lain pihak, studi kasus juga berusaha mengembangkan pernyataan-pernyataan umum mengenai regularitas dalam struktur dan proses sosial (Mulyana, 2006: 202).

Pengumpulan data penelitian dilakukan melalui wawancara mendalam, observasi dan studi dokumentasi. Data yang terkumpul diorganisasikan dan dianalisis menggunakan tigakomponen analisis data yaitu reduksi data, penyajian data dan penarikan kesimpulan.

Ketiga tahap analisis data tersebut dilakukan secara simultan dan terus menerus berlangsung serta saling berhubungan selama proses pengumpulan data di lapangan, sehingga dapat disebut juga dengan model interaktif. Skema ketiga komponen analisis data dapat dilihat pada gambar dibawah ini: 


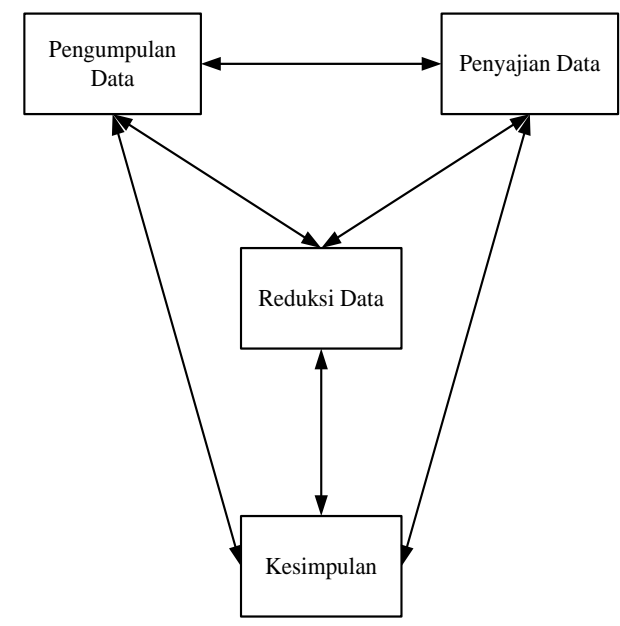

Gambar 1. Analisis Data Interaktif

Sumber: Miles dan Huberman

(dalam Agus Salim, Teori dan

Paradigma Penelitian Kualitatif, 2006: 22).

\section{Hasil dan Pembahasan}

\section{1) Pesan Komunikasi}

Pesan komunikasi yang disampaikan oleh Komunitas Hong kepada masyarakat dapat berupa pesan verbal maupun pesan non-verbal, pesan non-verbal ditujukkan dalam bentuk komunikasi objek dan gerak dalam setiap penampilan komunitas. Pesan dirancang sesuai konteks dan konten informasi yang tercermin dalam perilaku pada saat berkomunikasi. Berdasarkan hasil observasi yang dilakukan, beberapa perilaku yang ditunjukkan oleh komunitas Hong pada saat berinteraksi dengan komunikan, yakni: canda, senda gurau dan guyonan; menjelaskan dan mengajarkan; mempertunjukkan; mengenakan pakaian khas; memohon izin, fasilitasi; pelestarian dan dukungan kebijakan; gotong royong; kebersamaan; kemufakatan; mengingatkan; gotong royong; berbagi informasi; menghargai; kerjasama; nirlaba; ajakan rereongan;

Inti pesan komunikasi yang disampaikan adalah berupa himbauan dan ajakan untuk ikut bermain dan melestarikan permainan dan mainan rakyat Jawa Barat.

2) Media Sosialisasi

a. Internet

Komunitas Hong memanfaatkan internet sebagai saluran sosialisasi mainan dan permainan rakyat yang mereka kembangkan Dulu, sekitar tahun 2009, komunitas Hong pernah menggunakan blog multiply sebagai salah satu media komunikasi di internet. Di dalam situs multiply, ditampilkan informasi mengenai Komunitas Hong, di antaranya tentang profil dan kegiatan komunitas. Seiring ditutupnya blog multiply, maka aktifitas yang dilakukan oleh Komunitas Hong, kini disosialisasikan melalui media jejaring sosial Facebook. Media yang baru ini, selain memuat informasi mengenai Komunitas Hong, juga sebagai media silaturahmi dengan mereka yang pernah berkunjung ke Komunitas Hong. Foto-foto aktifitas yang dilakukan pengunjung ke Komunitas Hong, dapat ditampilkan di laman Facebook milik Komunitas Hong.

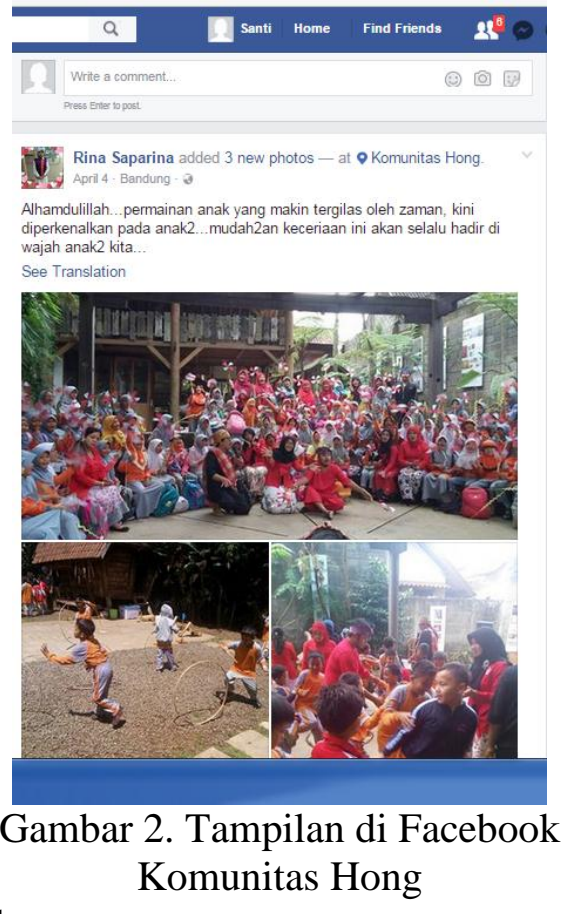

Sumber:

www.facebook.com/pages/KomunitasHong/

b. Media Massa

Salah satu saluran komunikasi yang efektif dalam menyebarkan informasi adalah melalui media massa. Media elektronik seperti televisi dan radio dimanfaatkan untuk menyampaikan informasi mengenai keberadaan Komunitas Hong ini. Televisi adalah salah 
satu media komunikasi massa yang paling powerfull karena audiensnya mencapai jutaan orang. Beberapa stasiun televisi yang pernah meliput komunitas Hong diantaranya adalah Trans TV acara Surat Sahabat, Laptop Si Unyil di Trans7, PJTV, TPI, RCTI dan Liputan 6 SCTV.

Selain televisi, Radio adalah media elektronik yang digunakan sebagai media komunikasi dan sarana untuk menyampaikan informasi. Melalui radio, Komunitas Hong menyuguhkan acara dalam bentuk talkshow. Beberapa radio yang pernah menyampaikan informasi mengenai Komunitas Hong adalah Radio Rama dan Radio Kosmo.

Selain media elektronik, media cetak pun menjadi salah satu media atau saluran untuk menyampaikan informasi mengenai Komunitas Hong. Beberapa media cetak yang pernah membuat pemberitaan tentang Komunitas Hong, diantaranya adalah Kompas, Pikiran Rakyat, Suara Pembaruan, Bandung Ekspress, Metro Bandung dan Galura.

c. Banner

Banner merupakan suatu alat yang cukup banyak digunakan orang untuk menginformasikan segala sesuatu. Komunitas Hong ini mempergunakan banner sebagai media untuk menginformasikan tentang keberadaan Komunitas ini. Banner ini biasanya dipasang ketika mengisi atau mengadakan sebuah acara, misalnya pada saat mengisi stan pameran ataupu kegiatan workshop. Dengan bentuk yang lebih besar dan menarik perhatian, membuat pengunjung dapat membaca mengenai keberadaan komunitas ini.

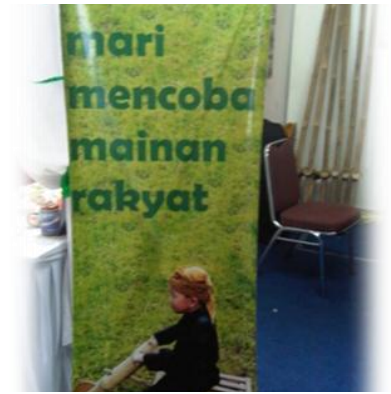

Gambar 2. Banner Komunitas Hong

Sumber: Koleksi Peneliti

Untuk media sosialisasi mainan dan permainan rakyat ini, Komunitas Hong belum memiliki media khusus seperti VCD, leaflet ataupun brosur. Untuk peralatan khusus di lapangan saat menjelaskan dan mendemonstrasikan mengenai permainan dan mainan anak inipun mereka hanya menggunakan peralatan yang ada, yang biasa digunakan sehari-hari. Seperti yang diutarakan oleh Abah Ajun:

"Brosur, leaflet atau VCD belum ada, cuman untuk komunikasi ataupun peralatan khusus di lapanganpun tidak ada, maka secara spontanitas saja langsung, misalnya ada yang bertanya main éngklé itu gimana?.. langsung saja dilapangan dipraktekkan, karena memang permainan rakyat itu begitu, tidak disiapkan, langsung saja di lapangan dipraktekkan."

Komunitas Hong mengikuti setiap kegiatan biasanya karena diundang oleh pihak penyelenggara kegiatan. Mereka belum pernah melakukan penawaran untuk mengisi kegiatan tertentu. Pihak yang mengundang biasanya adalah kenalan dari kang Zaini. Para penyelenggara kegiatankegiatan yang bersifat budaya, kemudian orang-orang yang mengetahui keberadaan Komunitas Hong ini melalui internet, maupun media cetak dan elektronik. Dan karena Komunitas ini bersifat non profit maka untuk biayanya disesuaikan dengan anggaran dari pihak penyelenggara.

Hal ini selaras dengan yang diutarakan oleh Abah Ajun,

"Sampai saat ini komunitas Hong 
belum menawarkan untuk turut serta dalam suatu event. Karena komunitas Hong ini non profit dimana ada event-event pun tidak ada target untuk mencapai sesuatu target materi."

Sementara untuk membiayai keberlangsungan Komunitas Hong, sumber dananya sebagian besar berasal dari dana pribadi. Seperti yang diutarakan oleh Abah Ajun:

"Selama ini untuk kelangsungan Komunitas Hong ini sebagian besar dari dana pribadi, dibantu kalau misalnya ada event-event, baru ada bantuan dari yang memanggil atau yang meminta Hong untuk tampil. Tapi itu tidak berkesinambungan, tapi hanya pas acara, selesai acara tidak ada sumber dana khusus."

Berdasarkan hasil observasi peneliti, pada saat berperan serta dalam suatu kegiatan atau mengadakan suatu kegiatan, para anggota Komunitas Hong mengenakan kostum khusus. Untuk anggota laki-laki mereka mengenakan pakaian kampret bewarna hitam dan celana komprang bewarna hitam.Kemudian mereka pun mengenakan ikat kepala yang terbuat dari kain batik.Ikat kepala ini memiliki nilai filosofi tersendiri, yaitu agar bisa tetap fokus dalam setiap langkah kehidupan. Sementara untuk anggota perempuan, mengenakan pakaian kampret bewarna hitam dan untuk padanannya, mengenakan kain kebaya batik yang dililitkan menyerupai rok. Anak-anak pun didandani wajahnya dan untuk tatanan rambut diselipkan bunga imitasi. Hal ini sejalan dengan yang diungkapkan Abah Adjun:

"Betul, ada ciri khas dari Komunitas Hong ini, yaitu pakaiannya. Pakaiannya itu adalah pakaian kampret, dimana pakaian itu pakaian zaman dahulu warnanya hitam, potongannyasederhana,yang perempuan pakai baju hitam kemudian bawahnya pakai kebaya pendek, yang laki-laki pakai komprang dan ikat kepala, komprang itu celana yang dipakai laki-laki, warnanya juga hitam. Antara kampret dengan komprang itu satu stel dengan memakai ikat kepala."

Komunitas Hong ini mengisi acara dalam bentuk festival, workshop, ataupun perayaan. Pada saat mengisi kegiatan, Komunitas Hong biasanya mengisi kegiatan tersebut dengan helaran. Para anggota Komunitas Hong berkeliling mengitari area kegiatan dengan membentuk barisan. Anak-anak perempuan berada dalam barisan sambil melambaikan dedaunan menggunakan tangan kanannya, sementara tangan kiri mereka letakkan di pinggang (berkacak pinggang). Sementara anak laki-laki dan beberapa lelaki dewasapun turut bergabung dalam barisan sambil membawa beberapa alat musik seperi angklung dan celempung. Setelah itu seluruh anggota Komunitas Hong berjalan beriringan membentuk arak-arakan dimana anak perempuan melambaikan daun dan anggota laki-laki Komunitas Hong membunyikan alat musik yang dibawanya. Biasanya mereka berjalan sambil berteriak 'Heeeey ya!'.

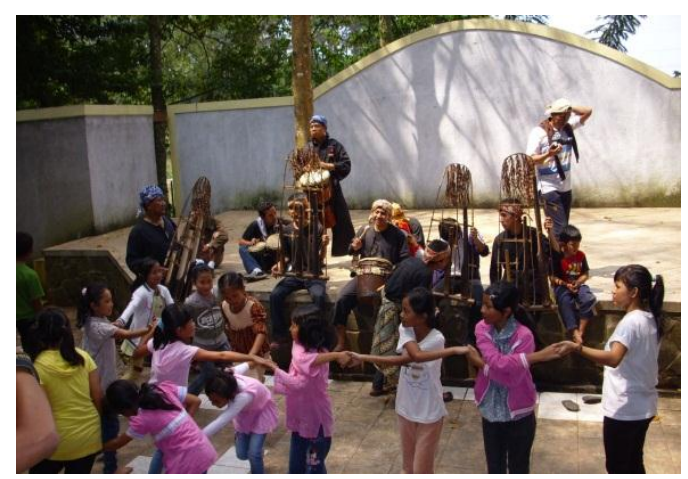

Gambar 3. Kegiatan Komunitas Hong dalam Memainkan Alat Musik

Sumber: Koleksi Peneliti

Setelah selesai helaran, mereka biasanya berhenti di suatu tempat yang telah ditentukan, kemudian Komunitas Hong ini dibagi menjadi beberapa kelompok. Kelompok pertama terdiri dari 
laki-laki dewasa dan remaja sementara kelompok dua terdiri dari anak-anak perempuan dan laki-laki.Kelompok pertama bertugas memainkan alat musik atau sembari melantunkan lagu yang nantinya mengiringi kelompok dua yang bertugas mendemonstrasikan permainan anak seperti perepet jengkol, oray-orayan, terkadang ada beberapa anggota komunitas Hong, disela-sela mendemonstrasikan permainan, mereka mengajak audiens untuk turut serta mencoba melakukan permainan tersebut.

Untuk beberapa kegiatan, pada saat anggota Komunitas Hong sedang mendemonstrasikan permainan dan mainan anak tersebut diiringi dengan kelompok perkusi, Kang Zaini atau Abah Adjun biasanya memberikan pengarahan atau keterangan mengenai permainan dan mainan yang sedang didemonstrasikan. Selain itu anggota Komunitas Hong lainnya, ikut membantu para audiens saat mereka ingin mempraktekkan permainan dan cara membuat mainan.

Setelah selesai mendemonstrasikan mainan dan permainan anak, mereka kembali melakukan helaran. Jika mendapat stan untuk pameran, Komunitas Hong biasanya memamerkan hasil karya para anggota Komunitas Hong, selain memamerkan, mereka pun menjual hasil karya tersebut.

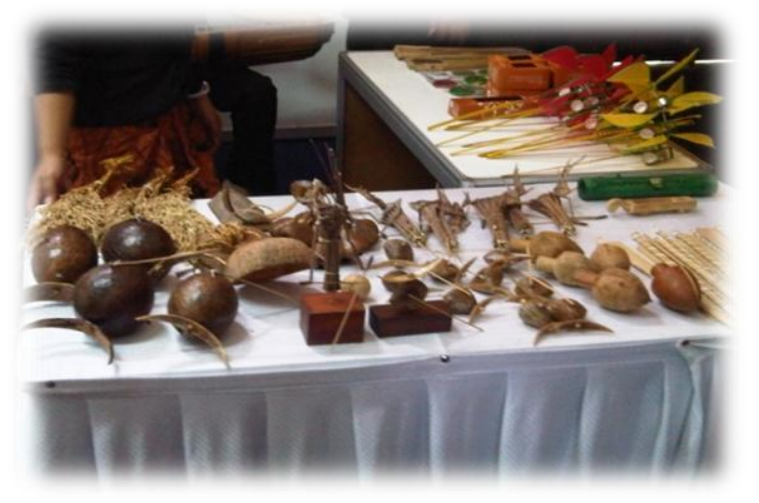

Gambar 4. Koleksi Mainan yang diperjualbelikan saat Pameran

Sumber: Koleksi Peneliti

Untuk setiap kegiatan, para koordinator bertanggungjawab terhadap bidangnya masing-masing. Seperti pada saat kegiatan workshop, koordinator kerajinan bertanggung jawab untuk mengajarkan cara pembuatan kerajinan baik itu kepada anggota Komunitas Hong (internal) maupun kepada audiens (eksternal). Dan pada beberapa kegiatan Komunitas Hong selain menampilkan helaran dan demo permainan dan mainan anak, kelompok tari permainan anakpun turut mementaskan tarian tradisional.

Proses Perancangan Pesan Komunikasi Komunitas Hong:

Jika dilihat dari empat kategori kegiatan komunikasi yang dilakukan Komunitas Hong pada tabel 1, terlihat bahwa upaya komunikasi yang dilakukan oleh Komunitas Hong telah memenuhi karakteristik suatu strategi komunikasi dengan alasan: (1) dari dua belas event yang di ikuti, direncanakan dengan matang, (2) memiliki tujuan yang jelas, yaitu mengenalkan, mempromosikan dengan harapan minat terhadap mainan dan permainan rakyat Jawa Barat dapat tetap lestari di bumi pertiwi ini, (3) event demi event yang diikuti dilakukan secara bertahap dan setiap akhir event dilakukan koordinasi dan evaluasi guna melakukan perbaikan (improvement) untuk diterapkan pada event berikutnya, (4) pendekatan dilakukan secara terintegrasi dalam satu kesatuan paket mulai dari mengajari cara membuat hingga cara memainkan, (5) jenis mainan dan permainan yang diperagakan tentu disesuaikan dengan konteks tema event yang diikuti.

\begin{tabular}{|c|c|}
\hline $\begin{array}{c}\text { Kategori } \\
\text { Kegiatan } \\
\text { Komunikasi }\end{array}$ & $\begin{array}{c}\text { Bentuk Kegiatan yang } \\
\text { Diikuti/Dilakukan }\end{array}$ \\
\hline Workshop & $\begin{array}{c}\text { - Sundanesse \& Books } \\
\text { Goes to Mall } \\
\text { Workshop Permainan } \\
\text { dan Mainan Rakyat } \\
\text { Tradisional di Taman } \\
\text { Hutan Raya }\end{array}$ \\
\hline Festival & $\begin{array}{c}\text { - World Bamboo } \\
\text { Festival } \\
\bullet \text { Festival Kolecer }\end{array}$ \\
\hline
\end{tabular}




\begin{tabular}{|c|c|}
\hline \multirow{7}{*}{ Kemitraan } & $\bullet$ Spice Fest 2008 \\
& $\bullet$ Festival Braga \\
& $\bullet$ Dies Emas ITB 2009 \\
\hline & Kerjasama dengan : \\
& $\bullet$ Al-Irsyad Satya \\
Islamic School \\
& $\bullet$ TK Harapan Bunda \\
& Dinas Pariwisata, \\
& Kehutanan dll. \\
& Pembaga \\
& $\bullet$ Internet \\
\hline \multirow{4}{*}{ Publikasi } & $\bullet$ Hubungan dengan \\
& Media \\
\hline
\end{tabular}

Tabel 1. Kegiatan Komunikasi Komunitas Hong

Konteks penelitian ini menyangkut budaya dalam arti objek penelitian berkaitan dengan kebudayaan dan subjek penelitian berkaitan erat dengan para budayawan baik dalam kapasitas sebagai penggiat, pemerhati, maupun sebagai partisipan. Kedekatan hubungan antara budaya dengan komunikasi dapat dijelaskan oleh Edward T. Hall dalam Mulyana dan Solatun (2007: 88) mengatakan bahwa communication is culture and culture is communication. Dalam banyak hal, hubungan antara budaya dan komunikasi bersifat timbal balik dan saling mempengaruhi. Hall mengingatkan bahwa budaya mempengaruhi bagaimana manusia berpikir dan apa yang dipikirkannya. Apa yang dibicarakan, bagaimana membicarakannya dan apa yang dilihatnya turut membentuk dan menentukan serta menghidupkan suatu budaya. Budaya tidak akanhidup tanpa komunikasi dan komunikasi tidak akan hidup tanpa budaya, masing masing tidak dapat berubah tanpa menyebabkan perubahan terhadap yang lainnya.

Pernyataan di atas akan memiliki konsekuensi, budaya merupakan landasan komunikasi. Bila budaya beraneka ragam, maka akan beraneka ragam pula praktekpraktek komunikasi yang berlangsung.
Berdasarkan hasil analisis peneliti, tahapan komunikasi yang dilakukan oleh Komunitas Hong yang ditujukan kepada khalayak sasarannya dibagi dalam 5 (lima) tahap sebagai berikut: a) menentukan sasaran komunikasi, b) identifikasi khalayak sasaran, c) mendefinisikan sistem pengelolaan kegiatan komunikasi, sebagai penyelenggara atau mengisi kegiatan, d) penyiapan sarana dan prasarana (meliputi penyiapan sumber daya dan fasilitas, menentukan saluran komunikasi, perancangan pesan dan menentukan komunikator), dan e) pengiriman pesan.

a. Menentukan Sasaran Komunikasi

Tahap awal dari penyusunan strategi komunikasi Komunitas Hong dalam melestarikan permainan dan mainan rakyat Jawa Barat adalah menentukan sasaran komunikasi, karena dengan mengetahui siapa yang menjadi sasaran komunikasi, maka kita dapat mengetahui tahapan apa lagi yang harus dilakukan dalam menyusun strategi. Secara umum, tujuan komunikasi dari setiap kegiatan yang dilakukan adalah melestarikan ragam mainan dan permainan rakyat suku Sunda. Secara spesifik, yang menjadi sasaran komunikasi adari setiap kegiatan yang dilakukan oleh Komunitas Hong adalah sebagai berikut:

\begin{tabular}{|c|c|c|}
\hline No. & Khalayak & Tujuan Komunikasi \\
\hline 1 & Publik & $\begin{array}{lr}\text { Meningkatkan } & \text { animo } \\
\text { masyarakat } & \text { terhadap } \\
\text { mainan } & \text { dan } \\
\text { permainan } & \text { rakyat } \\
\text { suku Sunda. } & \\
\end{array}$ \\
\hline 2 & Pemerintah & 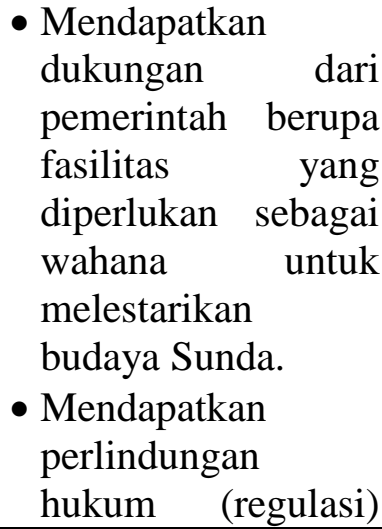 \\
\hline
\end{tabular}




\begin{tabular}{|l|l|l|}
\hline & & $\begin{array}{l}\text { tentang mainan dan } \\
\text { permainan rakyat } \\
\text { agar menjadi bagian } \\
\text { dari budaya Jawa } \\
\text { Barat yang perlu } \\
\text { dilestarikan. }\end{array}$ \\
\hline 3 & $\begin{array}{l}\text { Anggota } \\
\text { Komunitas }\end{array}$ & $\begin{array}{l}\text { Menggalang } \\
\text { konsistensi komitmen } \\
\text { pelestarian budaya } \\
\text { Sunda. }\end{array}$ \\
\hline 4 & Mitra & $\begin{array}{l}\text { Ajakan sinergi dalam } \\
\text { melestarikan mainan } \\
\text { dan permainan rakyat } \\
\text { suku Sunda. }\end{array}$ \\
\hline 5 & $\begin{array}{l}\text { Rereongan, } \\
\text { mendapatkan } \\
\text { dukungan partisipasi } \\
\text { dan } \\
\text { pembiayaan untuk } \\
\text { suksesnya acara. }\end{array}$ \\
\hline
\end{tabular}

Tabel 2. Tujuan Komunikasi dalam

Berkomunikasi dengan Khalayak Sasaran

b. Mengidentifikasi Karakteristik

Khalayak Sasaran

Pada tahap ini, Komunitas Hong mengidentifikasi karakteritis khalayak sasaran. Identifikasi dimaksud adalah mengenali siapa yang menjadi khalayak komunikasi?, apa fungsi dan peranannya?, bagaimana kemungkinan persepsi khalayak sasaran terhadap kegiatan Komunitas Hong? Tahapan ini menjadi sangat penting, karena hasil identifikasi dan analisis tentang khalayak sasaran dijadikan sebagai rujukan dalam menentukan langkah selanjutnya.

Berikut dijelaskan beberapa kemungkinan fungsi dan peranan khalayak sasaran komunikasi :

(a) Publik; dapat berperan sebagai kontrol sosial (social control), juga sebagai sebagai pendukung (supporter) dan suatu saat publik dapat mengambil peran sebagai pelaksana (executor). Untuk itu, harus dipahami karakteristik dan persepsi publik yang dihadapi. (b) Pemerintah; memegang fungsi dan peranan yang sangat besar terhadap keberhasilan program Komunitas Hong, sebab, tanpa peran serta dan dukungan dari pemerintah akan sulit mencapai hasil yang maksimal. Hal ini berkenaan dengan fungsi dan peranan pemerintah sebagai fasilitator tumbuh kembangnya budaya mainan dan permainan rakyat Sunda, juga sebagai stabilisator, dinamisator dan promotor, serta akselerator dalam pembangunan, termasuk didalamnya pengembangan dan pelestarian kekayaan budaya lokal.

(c) Komunitas Hong; Penggiat, merupakan motor penggerak utama (prime mover) dalam menjaga kelestarian mainan dan permainan rakyat Sunda. Komunitas ini harus menjadi lokomotif yang dapat menarik gerbong keanekaragaman mainan dan permainan dan harus menjadi pelayan dan memberikan rasa aman dan nyaman kepada setiap penumpang (anak-anak) yang menaiki gerbong tersebut sehingga jumlah penumpangnya dari masa ke masa terus bertambah.

(d) Mitra; memiliki peran sebagai akselerator dan promotor, sebab, keberhasilan di era globalisasi ini dapat dicapai melalui kerjasama (partnership) dengan pola sinergi, Komunitas Hong harus mampu tumbuh dan berkembang melalui jejaring (networking) mitra dan jangan menutup diri terhadap mitra serta berjalan sendiri tanpa mitra, karena percepatan (akselerasi) hanya bisa terjadi melalui kerjasama kemitraan strategis. Sebagai contoh, melalui kerjasama dengan sekolahsekolah dasar, Komunitas Hong dapat dengan mudah bertemu dan mengumpulkan anak-anak dalam jumlah besar. Cerita tentang mainan dan permainan rakyat yang didapat 
anak-anak dari komunitas Hong akan terus dikenang, dimainkan dan diceritakan kembali dari mulut ke mulut oleh mereka kepada warga di luar sekolah. Bisa dibayangkan, apabila suatu saat mainan dan permainan rakyat ini menjadi bagian dari muatan lokal pada sistem kurikulum di TK atau SD, maka niscaya mainan dan permainan rakyat Jawa Barat kelestariannya tetap terjaga.

(e) Sponsor; tidak ada satu pun kegiatan yang tidak memerlukan pendanaan, apa pun bentuknya, ditahap awal pola sponsorship yang dikembangkan adalah konsep rereongan dimana sumber pendanaan banyak digali melalui internal anggota. Namun, melihat eksistensi dan perkembangan komunitas Hong semakin mendapat tempat, maka persepsi sponsor harus menjadi bahan pertimbangan dalam menentukan strategi penggalangan biaya.

c. Menganalisis

Sistem

Penyelenggaraan Kegiatan Komunikasi

Setelah mengetahui khalayak sasaran dan memahami karakteristik khalayak, maka tahap selanjutnya adalah menganalisis sistem pengelolaan kegiatan komunikasi yang harus dilakukan.

Ada dua alternatif sistem pengelolaan penyelenggaraan kegiatan komunikasi, yaitu: dilakukan secara sendiri atau mengikuti event yang ada. Masing-masing bentuk penyelenggaraan memiliki kelebihan dan kekurangan, untuk itu Komunitas Hong harus cermat menyiasati peluang yang ada. Berikut beberapa hasil analisis pro-kontra sistem penyelenggaraan kegiatan.

\begin{tabular}{|c|c|c|}
\hline \multirow{2}{*}{ Kriteria } & \multicolumn{2}{|c|}{ Pro-Kontra } \\
\cline { 2 - 3 } & $\begin{array}{c}\text { Diseleng- } \\
\text { garakan } \\
\text { Sendiri }\end{array}$ & $\begin{array}{c}\text { Ikut } \text { event } \\
\text { yang Ada }\end{array}$ \\
\hline Tema & $\begin{array}{c}\text { Dapat } \\
\text { disesuaikan }\end{array}$ & $\begin{array}{c}\text { Harus } \\
\text { mengikuti }\end{array}$ \\
\hline
\end{tabular}

\begin{tabular}{|c|c|c|}
\hline Waktu & $\begin{array}{c}\text { dengan } \\
\text { Kebutuhan }\end{array}$ & $\begin{array}{c}\text { tema yang } \\
\text { ada (Term } \\
\text { and } \\
\text { Condition) }\end{array}$ \\
\hline Febih \\
Fempat & $\begin{array}{c}\text { Lebih } \\
\text { Fleksibel } \\
\text { ditentukan }\end{array}$ & $\begin{array}{c}\text { Telah } \\
\text { ditentukan }\end{array}$ \\
\hline $\begin{array}{c}\text { Khalayak } \\
\text { Sasaran }\end{array}$ & $\begin{array}{c}\text { Dapat } \\
\text { dikondisi- } \\
\text { kan }\end{array}$ & $\begin{array}{c}\text { Tergantung } \\
\text { tema besar } \\
\text { Event }\end{array}$ \\
\hline $\begin{array}{c}\text { Kesiapan } \\
\text { Sumber } \\
\text { Daya }\end{array}$ & $\begin{array}{c}\text { Lebih } \\
\text { Banyak }\end{array}$ & $\begin{array}{c}\text { Sesuai } \\
\text { Kebutuhan }\end{array}$ \\
\hline $\begin{array}{c}\text { Sistem } \\
\text { Pengelolaan }\end{array}$ & Amatiran & Profesional \\
\hline $\begin{array}{c}\text { Kebutuhan } \\
\text { Dana }\end{array}$ & Lebih besar & $\begin{array}{c}\text { Sesuai } \\
\text { kebutuhan }\end{array}$ \\
\hline
\end{tabular}

Tabel 3. Analisis Pro-Kontra Sistem

Penyelenggaraan Kegiatan Komunikasi

d. Penyiapan Sarana dan Prasarana Komunikasi

Yang dimaksud dengan sarana dan prasarana komunikasi dalam penelitian ini adalah: penyiapan sumber daya dan fasilitas, menentukan saluran komunikasi, perancangan pesan, dan menentukan komunikator.

(a) Penyiapan Sumber Daya dan

Fasilitas

Salah satu ciri dari Komunitas Hong dalam setiap penampilannya adalah mengenakan pakaian khas (kampret dan kebaya) dilengkapi oleh atribut yang menggambarkan ciri dan perilaku yang unik dari Komunitas hong. Sedangkan yang dimaksud dengan penyiapan fasilitas adalah penyiapan perlengkapan yang akan dipergunakan pada setiap penampilan.

(b) Menentukan Saluran Komunikasi

Strategi pemilihan saluaran komunikasi dipengaruhi oleh siapa yang menjadi khalayak sasaran, Komunitas Hong sangat memperhatikan kepada siapa mereka berhubungan dan untuk apa?, karena itu tanpa disadari sejatinya 
Komunitas Hong telah menggunakan strategi dalam setiap proses komunikasi yang dilakukan. Berdasarkan pengamatan peneliti, Komunitas Hong menggunakan kombinasi strategi komunikasi dengan pendekatan Internaldan Eksternal. Komunikasi Internal adalah komunikasi yang dilakukan antar komunitas dalam bentuk menggalang kebersamaan. Sedangkan komunikasi eksternal dilakukan dengan cara melakukan kegiatan untuk membangun opini publik. Saluran komunikasi yang paling banyak dipergunakan oleh Komunitas Hong adalah melalui tatap muka.

(c) Perancangan Pesan Komunikasi

Berikut tahapan dalam merancang pesan komunikasi Komunitas Hong berdasarkan khalayak sasaran yang dituju:

a) pendekatan dengan publik; pesan disampaikan melalui canda, senda gurau dan guyonan, menjelaskan dan mengajarkan, mempertunjukkan, mengenakan pakaian khas; b) pendekatan dengan pemerintah; isi pesan disampaikan melalui permohonan perizinan, kemudahan dan fasilitasi yang berkaitan dengan pelestarian mainan dan permainan rakyat Sunda; dukungan kebijakan, misalnya dalam memperjuangkan mainan dan permainan rakyat Jawa Barat agar dimasukkan menjadi muatan lokal pada pendidikan pra sekolah; c) pendekatan dengan anggota komunitas; dilakukan melalui gotong royong, kebersamaan, kemufakatan, mengingatkan, canda dan senda gurau, koordinasi, mengajarkan dan menghargai; d) pendekatan dengan Mitra; dilakukan melalui berbagi informasi (sharing of information), menghargai (respect), kerjasama (cooperation), nirlaba (non profit oriented); e) Pendekatan dengan sponsor; isi pesan yang dikomunikasi berupa ajakan rereongan dan menjelaskan.

(d) Menentukan Komunikator

Secara strategi, pendekatan dalam menentukan komunikator, komunitas Hong memilih menggunakan kredibilitas anggota komunitas (source of creadibility). Hal ini dimungkinkan mengingat hampir setiap pementasan dilakukan secara kolosal, sehingga sulit sekali mentukan 1 (satu) figur yang menjadi komunikatornya.

e. Pengiriman Pesan

Tahap terakhir adalah pengiriman pesan; pesan disampaikan pada saat dan tempat yang tepat. Agar dapat melihat hubungan keterkaitan (interaksi dan interdependensi) antara suatu tahap dengan tahap yang lainnya, peneliti menggunakan pendekatan Form to Chart yang menggambarkan aliran informasi dari satu tahap ke tahap yang lain dan informasi yang dihasilkan. Berikut ilustrasi aliran informasi dari setiap tahapan proses komunikasi yang dilakukan oleh komunitas Hong.

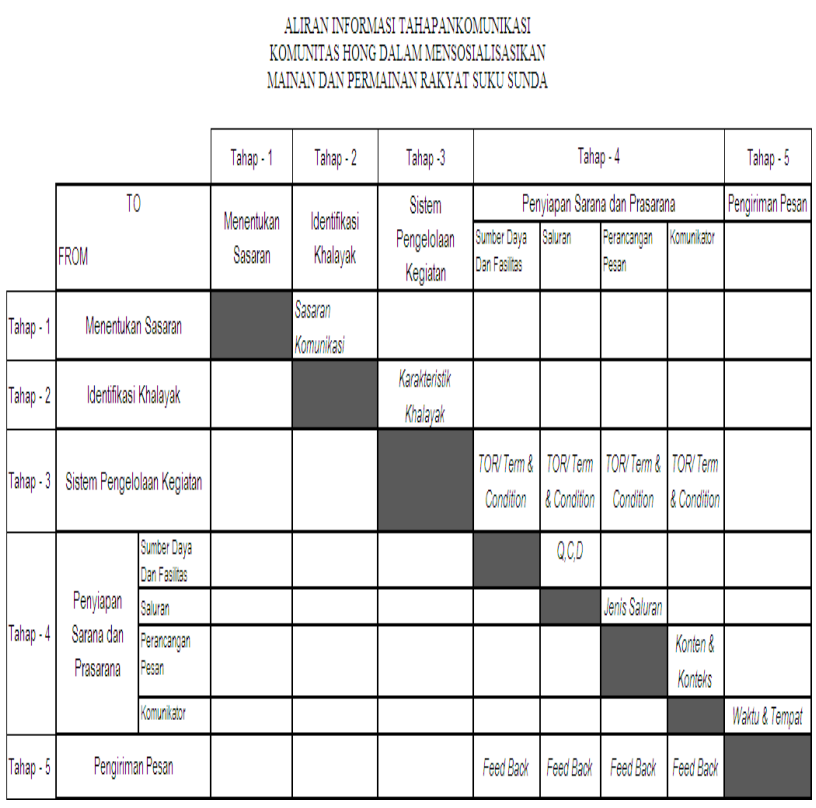




\section{Penutup}

Berdasarkan hasil analisis dari kegiatan festival, workshop, kerjasama dengan lembaga pendidikan, dan hubungan masyarakat, maka peneliti dapat mengelompokkan 5 (lima) kelompok besar komunikan, yaitu: (1) publik, (2) pemerintah, (3) sesama anggota Komunitas Hong, (4) mitra kerja dan (5) sponsor.

Dalam melakukan tindakan komunikasi, Komunitas Hong memiliki proses perancangan tahapan komunikasi yang sistematis, terencana dan terstruktur, mulai dari menentukan sasaran komunikasi, identifikasi khalayak sasaran, mendefinisikan sistem pengelolaan kegiatan komunikasi, sebagai penyelenggara atau mengisi kegiatan, penyiapan sarana dan prasarana (meliputi penyiapan sumber daya dan fasilitas, menentukan saluran komunikasi, perancangan pesan, dan menentukan komunikator) hingga pengiriman pesan. Hal ini dilakukan karena Komunitas Hong menganggap bahwa pesan dapat mempunyai pengaruh yang besar untuk mengubah perilaku khalayak.

\section{Daftar Pustaka}

Mulyana, D. (2006). Metodologi Penelitian Kualitatif. Bandung: Remaja Rosdakarya.

Mulyana, D. \& Solatun. (2007). Metode Penelitian Komunikasi. Contohcontoh Penelitian Kualitatif dengan Pendekatan Praktis. Bandung: Remaja Rosdakarya.

Salim, A. (2006). Teori dan Paradigma Penelitian Sosial: Buku Sumber untuk Penelitian Kualitatif. Jakarta: Tiara Wacana.

Alif, M. Z. (2006). Perubahan dan Pengembangan Bentuk, Fungsi dan Material Mainan Dalam Permainan anak di Masyarakat Sunda. Tesis. Bandung: Program Pascasarjana Institut Teknologi Bandung.

Yonathan, A. (2009). Perancangan Buku 'Ulin Yu!!' sebagai upaya pelestarian Permainan Rakyat Jawa Barat. Skripsi. Bandung: Program Sarjana Desain Komunikasi Visual. 